腓骨 の 疲 労骨折 2 例

長崎大学整形外科

大久保喬志・乗松 敏 晴・楢林好隆

森貞近見・鈴木良平

福岡市立病院

神 戸太郎

吉村外科病院

大塚 浩一

\title{
Two Cases of Stress Fracture of the Fibula
}

By

\section{T. Okubo, T. Norimatsu, Y. Narabayashi,}

T. Morisada \& R. Suzuki

Department of Orthopaedic Surgery, Nagasaki

University, School of Medicine

T. Kanbe

Fukuoka Municipal Hospital

K. Otsuka

Department of Surgery, Yoshimura Hospital

\begin{abstract}
The patients were both 16 years old males. After making an every-day-jumping-exercise from double knee bend for four days, they complained of pain at the lateral upper third of the legs.

By X-ray examination after two weeks they were diagnosed as stress fracture of the upper third of the fibula. Making conservative treatments for two weeks, the fractures united completely.
\end{abstract}

疲労骨折は, 以前軍隊の強行軍時, 最近ではスポー ツの基礎訓練時に主に，中足骨，脛骨にみられるもの で，腓骨の疲労骨折は，此較的稀といわれている．最 近われわれは, ウサギ跳びにて発生した，腓骨疲労骨 折の 2 例を経験したので若干の文献的考察を加えて報 告する.

症例 1,16 才の男子, 主訴両下腿上部痛, 初診 2 週間前, 野球部の基礎訓練として, 毎日約 $60 \mathrm{~m}$ の口 一カを 10 往復， ウサギ跳びをしていたとてろ，4 日 目より両下腿上部に痛みがあった。しばらく続けた が, 痛みがとれない為中止. その後安静にしていると 痛みはないが，下腿上外側部に物があたったり，立ち 上がり，階段の昇降時に痛みが続く為，当科受㟝. 全
身状態は良好，諸検査にても異常なし，両下腿上外側 部に圧痛あるも, 特に腫張, 発赤, 熱感は認められな い。初診時レ線にて, 両側腓骨上 $1 / 3$ 亿骨折像をみた ため, 安静理学療法を行ない, 約 2 週で痛みは消失. ての時のレ線にて骨折の回りに，著明な化骨形成を みた。

症例 2, 16 才の男子, 主訴は左下腿上部痛, 症例 1 と同じクラブ員である為, 受傷機転, 経過はほぼ同 じ,やはり 2 週後当科受誩. 初診時レ線にて左腓骨上 $1 / 3$ 亿骨折線を認めたためシーネ固定 2 週，ての時の レ線像にてやはり著明な, 骨膜反応がみられた，2人 とも 4 週にてクラブに復した（図1）. 


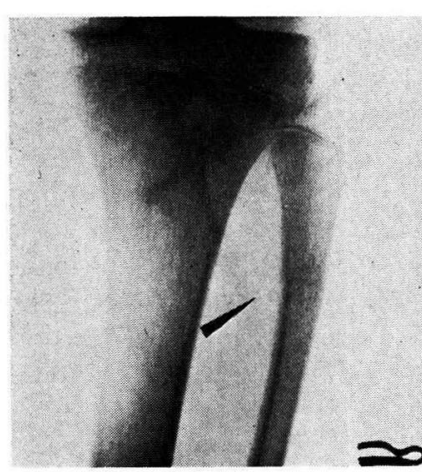

A 症状発現後 2 遇目

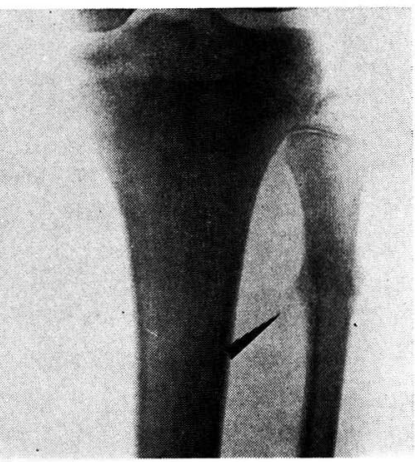

B 症状発現後 4 週目

図 1

考

案

疲労骨折の発生原因には, 栄養障害, ビタミン欠 乏, 局所性全身性の感染, 筋, 䩒帯などの張力による ものなど，いろいろいわれているが，その主因をなす ものは, 繰返しの, 機械的荷重であり, その忘力の最 も強く働いた部に発生する過労性骨障害である．Devasはスポーツによる50例の腓骨疲労骨折を検討し， 堅い路面を走行した者に多くみられることから，足底 屈筋群の反復収縮により，腓骨が弦運動を行なうこと を指摘して, 筋力による腓骨の疲学骨折が少なくない ことを強調している. Williams は, スポーツ選手は 過強な筋肉の発達がこれを支持するに足る骨格の発達 よりもまさり，てれが原因になるとのべている．発生 部位をみると疲学骨折の主因が主に機械的荷重である 為，下肢に多く，上肢その他にはほとんどみられな い. 特殊なものとしては, 頸椎のVII, 胸椎のI の棘突 起に生ずる土工病，ゴルフスフィング，長期の咳嗽発 作による肋骨々折等がある. 下肢のうちでも，その好

表 1 発生部 位

\begin{tabular}{|cr|cr|}
\hline Morris & 700例 & Asal & 600例 \\
\hline 中足骨 & $68 \%$ & 中足骨 & $81 \%$ \\
脛 骨 & $26 \%$ & 脛 骨 & $12 \%$ \\
腓 骨 & $1 \%$ & 腓 骨 & $2 \%$ \\
その他 & $5 \%$ & その他 & $5 \%$ \\
\hline
\end{tabular}

表 2 腓骨部位別発生数扣よび受傷機転

Burrow 90 例

\begin{tabular}{|c|c|c|c|}
\hline $\begin{array}{l}\text { 上 } \\
\text { 中 } \\
\text { 下 }\end{array}$ & $\begin{array}{l}1 / 3 \\
1 / 3 \\
3 / 1\end{array}$ & 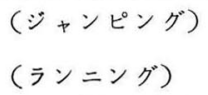 & $\begin{array}{r}66 \text { 例 } \\
3 \text { 例 } \\
21 \text { 例 }\end{array}$ \\
\hline
\end{tabular}

発部位は比較的限局されており，その ほとんどが, 中足骨, 睉骨にみられ る. 症例数の多い, Morris, Asal の 報告をみても, 中足骨, 脛骨で全体の 約 $90 \%$ 占めており, 腓骨の疲学骨 折は，1〜2\%と非常に少ない（表 1). Burrow は腓骨疲労骨折を下 $1 / 3$, 中 $1 / 3$, 上 $1 / 3$, と分け, その発 生数, 受傷機転などをくわしく調査し ている．それによると発生部位として は,上 $1 / 3$ が最っも多く約 $70 \%$, 次が 下 $1 / 3$ で約 $25 \%$,中 $1 / 3$ はほとんどな く約 $5 \%$ となっている.またその発生 機転として下 $1 / 3$ にランニングによるもの, 及びペタ ルふみを職業とする中年の女に, 上 $1 / 3$ に主にジャン プにより生ずるものが多いとしている（表 2 ）。なお 陘骨でも上下 $1 / 3$ に, 中足骨では $2 ， 3 ， 4$ 中足骨と， おおよそ，その発生部位はきまっており，乙れは同部 が, 解剖学的, 力学的に負荷をうけ易い場所であるこ とがうかがえる. 疲学骨折が, 行軍, スポーツの基礎 訓練時に発生するという性格上, 圧倒的に男子に多く みられ，それも 20 才前後に集中している. 最近の報 告をみるとそのほとんどが運動により発生している. 季節的には冬期, スポーツシーズンの初めの $3 \sim 5$ 月 に多くみられる.

症状の発現は骨折部の軽度の自発痛で, 普通の骨折 と異なり, その場で動けないというととはない. 中に はその時, 何んらの症状のないものもある. 腓骨の疲 労骨折の場合は足関節, 膝関節に鈍痛や, だるい感じ を訴えるととがある. また全荷重骨でない為, それ程 跛行も示さない。はとんどの症例に, 局所の圧痛があ り，それが骨の上に限局され，䩗帯の上にないてとが 捻挫等との鑑別になりうる. 腫張, 発赤, 熱感等はあ まりみられない. 化学的検査所見も全て正常である. 特に誘因となるものがないため, 患者は症状発現後 1 〜2 週間して受診する場合が多い.この時レ線でも認 めがたいくらいの，でく微細な不全骨折が骨膜下にお こっている. 漸次レ線にて横走する透明線としてみら れてくる. 純粋の疲労骨折は, 変形をおこすととはな いが, この時に外力をうけると容易に変形をおこしう る. 症状発現より $2 \sim 3$ 週すると，骨折部に一致し て，著明な骨膜反応をみることができる．との時点に おけるレ線が，骨腫場の好発部位に一致すると，時に 
その鑑別が容易でない場合があり，試験切除して，組 織にて，定型的化骨形成をみて確診するてともある. また従来傍骨性骨肉腫という表現で記載されている症 例の中にも，病期の長い疲労骨折が含まれているとの べる人もいる.治療は特に強固な固定を必要とせず, 普通の歩行を許す程度の安静, 弾力包帯固定にて, 約 2 〜 カ月で完治する. 中に仲々愁訴のとれない症例 があり,そういう症例に対して, 同部の切除, 骨移植 を行なった報告もあるが，一般に予後は，はなはだ良 好である.
文献

1) H. Jackson Burrow : J. B. J. S., vol. 30-B, 266, 1948.

2) M. B. Devas : J. B. J. S., vol. 38-B, 818 , 1956.

3) Asal : Arch. Klin. Chir. 186, 511, 1936.

4) Morris: Fatigne fractures (a clinical study), 1965.

5）菊地俊治：北海道整災誌. 12巻，1号，48-， 1967.

6）岩原宙猪・片山良亮：整形外科学.上巻

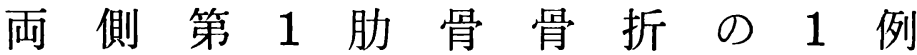

鹿児島大学医学部整形外科

東成 昭・森 本典夫

\section{Bilateral Fracture of the First Rib, A Case Report}

By

\author{
N. Higashi \& N. Morimoto \\ Department of Orthopedic Surgery, Faculty of \\ Medicine, Kagoshima University
}

肋骨骨折は，われわれが日常しばしば遭遇する骨折 であるが，第 1 肋骨は前方より鎖骨，後方より肩甲骨 および背部諸筋により保護されているため，その骨折 は比較的稀であり，特に両側性は極めて稀とされてい る.われわれが本邦文献を渉猟した限りでは，12 例 の両側第 1 助骨骨折の報告があるのみである.

われわれは今回, 交通事故で発生した両側第 1 助骨 折の1例を経験したので報告する。

\section{症例}

患者：36才, 男子, 自衛官

主訴 : 右顔面, 耳介の挫傷, 上胸部痛, 呼吸困難

家族歴, 既往歴：特記事項はない

現病歴：普通乗用車を運転し，交叉点を進行中，右 側面より進入してきたトラックに右後部ドア付近に衝 突された。事故後, 意識不明となったが，移送中意識 を回復した。
現症：意識は明瞭であったが，顏面荅白，苦閣状を 呈し，呼吸困難を訴えた．右顔面の挫傷よりの出血著 しく, 上胸部痛, 肩甲部痛, 両上肢の運動痛があり, 右肩甲部，両鎖骨上窩の著明な圧痛を認め，さらに皮 下気腫特有の捻髪音を両腋窩部に証明した。

X線所見：頭蓋, 頸, 胸, 腰椎, 骨艋部に異常を認 めず，胸部写真では両側第 1 助骨の鎖骨下動脈溝付近 亿鋸崡状の骨折線を認め特に左側は明瞭な第 3 骨片を 形成している.また両側第 2 肋骨の中央部に骨折線を， 右第 3 肋骨結節にはかすかな致骨折がみられる。

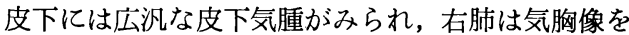
示している(図1・2).

検査所見: 赤血球 $303 \times 10^{4}$, 白血球 $5760, \mathrm{Hb} 63$ $\%$, Ht $30 \%$, 百分率は好中球 $74 \%$, 好酸球 $2 \%$, 淋巴球 $21 \%$, 単球 $3 \%$, 血沈 1 時間 $22 \mathrm{~mm}, 2$ 時間 $46 \mathrm{~mm}$, 尿一般異常なし, 血清化学的検査では総蛋白 $6.0 \mathrm{~g} / \mathrm{dl}$, Albumin $61.7 \%$, Globulin $\alpha 16.1 \%$, 